\title{
Effect of vitamin $E$ on the immune system of SPF birds vaccinated against infectious bronchitis virus
}

\author{
Efeito da vitamina $E$ sobre o sistema imununológico de aves SPF \\ vacinadas contra o vírus da bronquite infecciosa
}

\author{
Juliana Maria de Almeida ${ }^{1 *}$; Lenita Moura Stefani ${ }^{2}$; Wagner Loyola ${ }^{3}$; Everton Luis \\ $\mathrm{Krabbe}^{4}$; Claudia Yurika Tamehiro5; Rodrigo Guilherme Backes ${ }^{6}$; Claudia Pies \\ Biffi $^{7}$; Gabriella Bassi das Neves ${ }^{8}$; Wanderley Moreno Quinteiro Filho ${ }^{9}$
}

\begin{abstract}
In order to analyze the influence of vitamin $E$ on the immune response of birds vaccinated and challenged with Infectious Bronchitis Virus in poultry (IBV), and which dose of vitamin $\mathrm{E}$ is the best to answer this, an experiment was conducted using 50 SPF birds housed with one day of life at Embrapa - Suínos e Aves. All birds were divided into 10 groups of five birds each, including positive and negative control groups, supplemented with 15, 50, and $200 \mathrm{IU}$ of vitamin $\mathrm{E} / \mathrm{Kg}$ added into the feed. On the 14th day of life the birds were vaccinated with a commercial vaccine for infectious bronchitis $(\mathrm{H}-120)$ and after 28 days, one group for each treatment was challenged with IBV, strain classical (M-41). Five days after challenge birds were necropsied and abdominal macrophages were collected for analysis of microbicidal activity and measurement of nitric oxide (NO). The lung was collected for cell count by flow cytometry and also for NO dosage. Organs of predilection were also collected for histological analysis and virus isolation to analyze the efficiency of the vaccine. The results were evaluated by ANOVA and Student t-test. An increased of microbicidal activity of abdominal macrophages was observed in the groups of birds with higher levels of vitamin E (200 IU/Kg) supplementation when compared with groups that did not receive or received minor amounts $(0,15,50 \mathrm{IU} / \mathrm{Kg})$, indicating an improvement in the innate immune response influenced by vitamin E supplementation in the diet. The supplementation of this vitamin in high doses also increases the ability of macrophages to produce NO. And, by flow cytometry, suggests that the macrophages are the primary cells recruited in the lung tissue to combat infectious bronchitis and this action was potentiated by the addition of vitamin E, independent of the dosage.
\end{abstract}

Key words: Immunity, nutrition, vaccine, vitamin E

\footnotetext{
${ }^{1}$ Veterinária, Me. em Ciência Animal, Universidade do Estado de Santa Catarina, UDESC/CAV, Lages, SC, Brasil. E-mail: julianaalmeida40@hotmail.com

${ }^{2}$ Veterinária, PhD em Medicina Veterinária, Prof ${ }^{a}$ da UDESC/CEO, Chapecó, SC, Brasil. E-mail: borrucia@hotmail.com

${ }^{3}$ Biomédico, Dr. e Pesquisador da Embrapa Suínos e Aves, Concórdia, SC, Brasil. E-mail: wloybr@yahoo.com.br

${ }^{4}$ Eng $^{\circ}$ Agr $^{\circ}$, Dr. e Pesquisador da Embrapa Suínos e Aves, Concórdia, SC, Brasil. E-mail: everton.krabbe@embrapa.com

${ }^{5}$ Veterinária, Prof ${ }^{a}$ Dr $^{a}$, Universidade Estadual do Norte do Paraná, UENP/CLM, Bandeirantes, PR, Brasil. E-mail: claudiayurika@ uenp.edu.br

${ }^{6}$ Zootenista, M.e em Ciência Animal, UDESC/CAV, Lages, SC, Brasil. E-mail: rbackes@zootecnista.com.br

${ }^{7}$ Veterinária, M.e em Ciência Animal e Discente de Doutorado da UDESC/CAV, Lages, SC, Brasil. E-mail: claudiapies@yahoo. com.br

${ }^{8}$ Zootecnista, Discente Mestrado em Ciência Animal, UDESC/CAV, Lages, SC, Brasil. E-mail: gabi_zootec@yahoo.com.br

${ }^{9}$ Veterinário, Dr. em Patologia Experimental e Comparada, Universidade de São Paulo, USP, São Paulo, SP, Brasil. E-mail: quinteirofilho@gmail.com

* Author for correspondence
} 


\title{
Resumo
}

\begin{abstract}
A fim de analisar a influência da vitamina E sobre a resposta imunológica de aves vacinadas e desafiadas com o Vírus da Bronquite Infecciosa das aves (VBI), e qual dose da vitamina E é melhor para essa resposta, foi realizado um experimento utilizando 50 aves SPF alojadas com um dia de vida na Embrapa - Suínos e Aves. As aves foram divididas em 10 grupos de cinco aves cada, incluindo grupo controle positivo e negativo, suplementadas com 15,50 e $200 \mathrm{UI} / \mathrm{Kg}$ de vitamina $\mathrm{E}$ na ração. No décimo quarto dia de vida as aves foram vacinadas com a vacina comercial para Bronquite Infecciosa $(\mathrm{H}-$ 120) e após 28 dias, um grupo por tratamento foi desafiado com VBI cepa clássica (M-41). Cinco dias após o desafio as aves foram necropsiadas e os macrófagos abdominais foram coletados para análise da atividade microbicida e dosagem de óxido nítrico (NO). O pulmão foi coletado para contagem de células através de citometria de fluxo e também dosagem de NO. Órgãos de eleição também foram coletados para análise histológica e realização do isolamento viral para analisar a eficiência vacinal. Os resultados foram avaliados pelo teste ANOVA e Student t-test. Um aumento da atividade microbicida dos macrófagos abdominais foi observado nas aves com maior suplementação de vitamina E (200 UI/ $\mathrm{Kg})$ quando comparado com os grupos que não receberam ou receberam quantidades menores $(0,15,50$ $\mathrm{UI} / \mathrm{Kg}$ ), indicando uma melhora na resposta imune inata influenciada pela suplementação de vitamina E na dieta. A suplementação desta vitamina em altas dosagens também aumenta a capacidade dos macrófagos em produzir NO. E, através da citometria, sugere-se que os macrófagos são as principais células recrutadas no tecido pulmonar no combate a BI e esta ação foi potencializada pela adição da vitamina independente de dosagem.
\end{abstract}

Palavras-chave: Imunidade, nutrição, vacina, vitamina E

\section{Introduction}

Nutrition is very important for physical and physiological body development. Therefore several ingredients have been studied and used in animal feed to improve their performance and immune system (KLASING, 1998; KIDD, 2004). Vitamin E, for example, is known for being a potent antioxidant working as a modulator of the immune system. However, there is yet some disparity regarding the correct amount of it to be used. Studies conducted by Leshchinsky and Klasing (2001) demonstrated that moderate levels of vitamin E (25 to $50 \mathrm{IU} /$ $\mathrm{kg}$ ) in the diet induced better antibody production compared to those that received higher levels (100 to $200 \mathrm{IU} / \mathrm{kg}$ ). On the other hand, Konjufca et al. (2004) observed higher phagocytic activity of macrophages in broilers supplemented with high doses of vitamin E (110-220 mg/kg). These findings suggest that the diet plays an important role. Knowing the possible influence of vitamin E, a study of this micronutrient is important for poultry, since it can help in the control of many diseases such as Infectious Bronchitis (IB) of poultry, which is now endemic in our country.
The aims of this study were to analyze at what level of vitamin E may influence the innate and adaptive immune response by evaluating the cells that participate in these responses such as macrophages, lymphocytes and other mononuclear cell, and if this supplementation could potentialize the vaccination against IBV.

\section{Materials and Methods}

\section{Ethical approval}

The procedure was approved by the Animal Welfare Committee of Embrapa under approval number $013 / 2012$ on $23 / 08 / 2012$.

\section{Animals}

Fifty SPF one-day-old chicks were randomly distributed in ten groups of five animals each and treated with feed as proposed by Rostagno et al. (2011) supplemented with different levels of vitamin E. Food and water were provided ad libitum. 


\section{Treatments}

Three treatments with different levels of vitamin $\mathrm{E}(15,50$, and $200 \mathrm{IU} / \mathrm{kg})$ in the diet were used as are shown in Table 1, as follows: Group 1 - positive control only challenged; Group 2 - negative control without vaccine and without challenge; Group 3 vaccinated birds without vitamin E supplementation, Group 4 - birds without vitamin E supplementation, vaccinated and challenged; Group 5 - birds with 15 $\mathrm{IU} / \mathrm{kg}$ of vitamin E supplementation and vaccinated, Group 6 - birds with $15 \mathrm{IU} / \mathrm{kg}$ of vitamin E, vaccinated and challenged; Group 7 - birds with $50 \mathrm{IU} / \mathrm{kg}$ vitamin $\mathrm{E}$ and vaccinated; Group 8 birds with $50 \mathrm{IU} / \mathrm{kg}$ of vitamin $\mathrm{E}$, vaccinated and challenged; Group 9 - birds with $200 \mathrm{IU} / \mathrm{kg}$ of vitamin E and vaccinated and Group 10 - birds with $200 \mathrm{IU} / \mathrm{Kg}$ of vitamin E, vaccinated and challenged.

\section{Experimental design}

The birds were vaccinated on the fourteenth day of age using a commercial live attenuated vaccine (strain $\mathrm{H} 120$ ). The vaccine was titrated and administered at the dose of $10^{3,5} \mathrm{DIE}_{50}$ by the ocular route. Challenge was performed ocularly at three weeks after vaccination with a classical viral strain IBV (M41) on a dose of $10^{3,5} \mathrm{DIE}_{50}$ from Embrapa Suínos e Aves already tested for its viral infectivity.

After the challenge, all birds were examined daily to observe the presence of clinical signs of respiratory disease (prostration, nasal and ocular discharge, hoarseness, sneezing, conjunctivitis, anorexia and ruffled feathers). Three weeks after vaccination the birds were humanely euthanized by cervical dislocation.

Table 1. Animal distribution in the isolators according to treatment.

\begin{tabular}{ccccc}
\hline Group & $\begin{array}{c}\text { Number of } \\
\text { animals }\end{array}$ & Vit. E (UI/Kg) & $\begin{array}{c}\text { Vaccine BI } \\
(\text { H120) }\end{array}$ & Challenge (M41) \\
\hline 1 & 5 & 0 & NO & YES \\
2 & 5 & 0 & NO & NO \\
3 & 5 & 0 & YES & NO \\
4 & 5 & 0 & YES & YES \\
5 & 5 & 15 & YES & NO \\
6 & 5 & 15 & YES & YES \\
7 & 5 & 50 & YES & YES \\
8 & 5 & 50 & YES & NO \\
9 & 5 & 200 & YES & YES \\
10 & 5 & 200 &
\end{tabular}

H120 (Holland 120), viral strain present in the vaccine and M41 (Massachusetts 41- viral strain homologous to the vaccine). Source: Elaboration of the authors.

\section{Cellular immunity analysis}

Abdominal macrophages harvest

Sephadex G-40 was used to collect macrophages. These cells were washed as described by Sabet et al. (1977) modified by Trembicki, Dietert and Qureshi (1984).
Evaluation of microbicidal activity on abdominal macrophages

This test was performed as described by Campbell and Desiderio (1983) using Salmonella Enteritidis harvested in the log phase. Macrophages were placed in contact with the bacteria, and the supernatant was collected to measure NO. 
Flow cytometry for analysis of the alveolar macrophages

The lungs were removed, cut into small pieces, and treated with collagenase $(2 \mathrm{mg} / \mathrm{mL})$ in RPMI 1640 for 40 minutes in a shaker. The material was macerated, filtered, and then centrifuged. About 1 $\mathrm{ml}$ of the supernatant was used to measure nitric oxide. The pellet was centrifuged and resuspended twice on $2 \mathrm{~mL}$ PBS. Then was made a final dilution in a culture medium, containing fetal bovine serum and RPMI at a concentration of 1:10.

After this procedure, these samples were frozen at $-20^{\circ} \mathrm{C}$ and after 24 hours stored in a freezer at $-70^{\circ} \mathrm{C}$ until reading. Macrophages were marked with KUL 01 (Abcam, Cambridge, MA, USA) specific for Gallus gallus domesticus macrophages, as described by Mast et al. (1998). The amount of macrophages/monocytes present in the lungs was determined by the fluorescence intensity (average) and the percentage of stained cells (\%).

\section{Determination of nitric oxide (NO)}

The concentration of NO in the supernatant from the abdominal washes and lungs was determined using the Griess reagent ( $1 \%$ sulfanilamide, $0.1 \%$ of naftiletilenodiamina dihydrochloride, 2.5\% H3PO4) according to methodology previously described (GREEN; TANNENBAUM; GOLDMAN, 1981). ELISA assay was performed to determined nitrite concentration using a standard curve.

\section{Virus isolation test}

This step was performed by inoculating $0.2 \mathrm{~mL}$ of macerated trachea from experimental birds in embryonated SPF eggs with nine days of incubation via allantoic cavity. For this, five eggs were inoculated per sample and incubated for seven days at $37^{\circ} \mathrm{C}$. The candling was performed at the same time each day to check mortality. After seven days all embryos were examined looking for changes such as dwarfing and winding (OIE, 2008).

\section{Histopathology}

Samples of trachea, lung, kidney, spleen, and thymus were collected, placed into containers with $10 \%$ formaldehyde, cut and stained by hematoxylin-eosin method. Slides were readby optical microscopy and images were recorded using a camera coupled to the microscope and a computer program (Motic Images Plus ${ }^{\circledR}$ ). Five degrees of lesion severity were assigned, being zero the absence of histopathological findings and four the highest level.

\section{Statistical analysis}

The results were evaluated by analysis of variance (ANOVA) and Student t-test with a significance of $\mathrm{p}<0.05$.

\section{Results}

Evaluation of microbicidal activity of abdominal macrophages

A significant reduction $(\mathrm{P}<0.05)$ in the $\mathrm{S}$. Enteritidis inoculum was observed in groups treated with higher levels of vitamin E (200 IU/kg) when compared with the groups that did not receive, or received less amounts of vitamin E (15 and $50 \mathrm{IU} /$ $\mathrm{kg}$ ) as shown in Figure 1. 
Figure 1. Microbicidal activity of abdominal macrophages performed through contact with Salmonella enteritidis. Group 1 - positive control only challenged; Group 2 - negative control without vaccine and without challenge; Group 3 - vaccinated birds without vitamin E supplementation, Group 4 - birds without vitamin E supplementation, vaccinated and challenged; Group 5 - birds with $15 \mathrm{IU} / \mathrm{kg}$ of vitamin E supplementation and vaccinated, Group 6 birds with $15 \mathrm{IU} / \mathrm{kg}$ of vitamin E, vaccinated and challenged; Group 7 - birds with $50 \mathrm{IU} / \mathrm{kg}$ vitamin $\mathrm{E}$ and vaccinated; Group 8 - birds with $50 \mathrm{IU} / \mathrm{kg}$ of vitamin E, vaccinated and challenged; Group 9 - Birds with $200 \mathrm{IU} / \mathrm{kg}$ of vitamin E and vaccinated and Group 10 - birds with $200 \mathrm{IU} / \mathrm{Kg}$ of vitamin E, vaccinated and challenged.

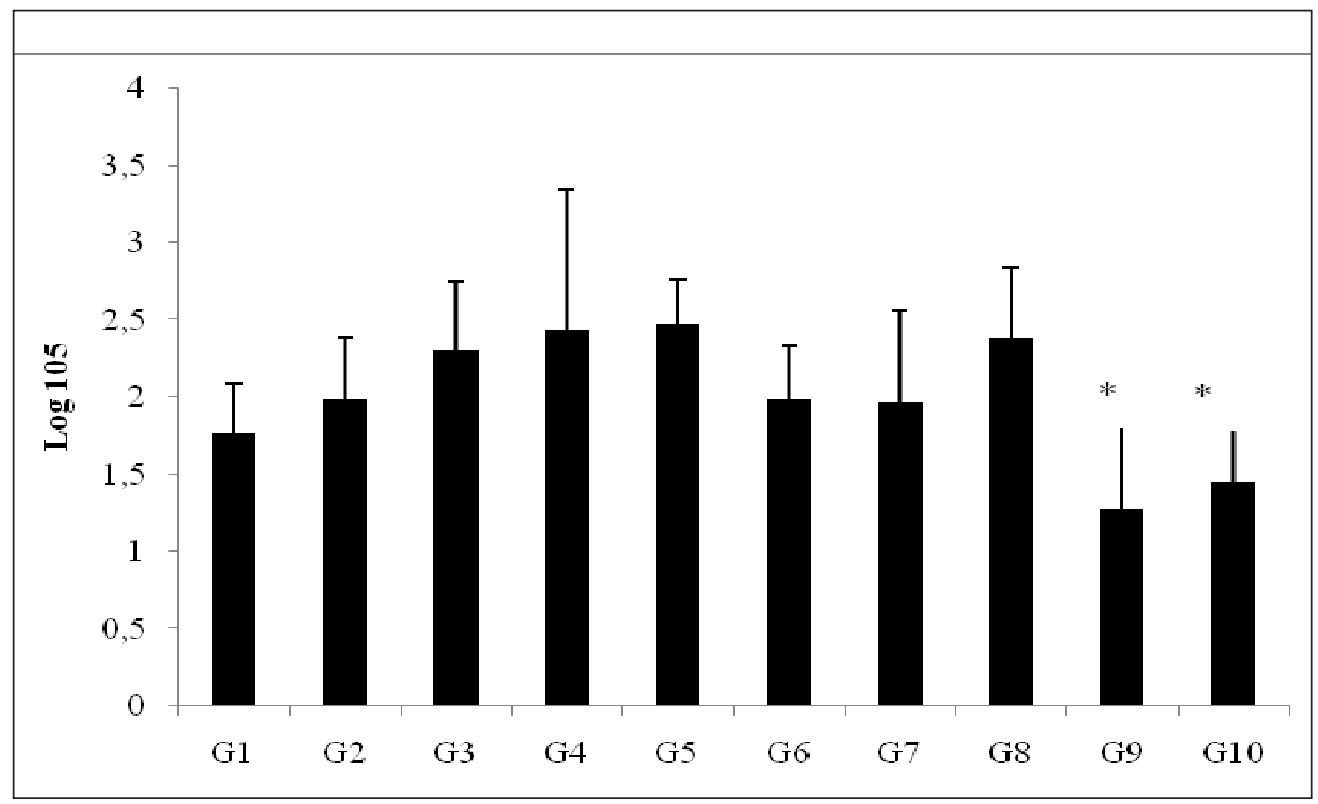

The vertical bars represent the amount of bacteria present in each group after the test (in $\log 10^{5}$ ).

* Groups with significant statistic differences $(\mathrm{P}<0.05)$.

Source: Elaboration of the authors.

\section{Determination of nitric oxide (NO)}

It was detected NO production in all groups, including controls. However, the group of vaccinated birds (Group 9), the vaccinated and challenged (Group 8 and 10) supplemented with high doses (50 and $200 \mathrm{IU} / \mathrm{kg}$ ) of vitamin E, and negative control group (Group 2) showed increased production of NO $(\mathrm{P}<0.05)$ as it can be seen in in Figure 2.
This suggests that, when the bird is immunized or challenged, there is an immunesupression caused by impairment on nitric oxide (NO) production. When the bird is supplemented with high doses of Vitamin E, even if vaccinated or challenged, this impairment does not occur, and the production of NO might be equal to a bird under homeostasis. This result suggests that supplementation with large doses of vitamin enhances macrophage ability to produce reactive nitrogen. 
Figure 2. Dosage of $\mathrm{NO}$ in $\mu \mathrm{M}$ from the abdominal macrophage to evaluate the microbicidal activity. Group 1 - positive control only challenged; Group 2 - negative control without vaccine and without challenge; Group 3 vaccinated birds without vitamin E supplementation; Group 4 - birds without vitamin E supplementation, vaccinated and challenged; Group 5 - birds with $15 \mathrm{IU} / \mathrm{kg}$ of vitamin E supplementation and vaccinated, Group 6 - birds with $15 \mathrm{IU} / \mathrm{kg}$ of vitamin E, vaccinated and challenged; Group 7 - birds with $50 \mathrm{IU} / \mathrm{kg}$ vitamin E and vaccinated; Group 8 - birds with $50 \mathrm{IU} / \mathrm{kg}$ of vitamin E, vaccinated and challenged; Group 9 - Birds with $200 \mathrm{IU} / \mathrm{kg}$ of vitamin E and vaccinated and Group 10 - birds with $200 \mathrm{IU} / \mathrm{Kg}$ of vitamin E, vaccinated and challenged.

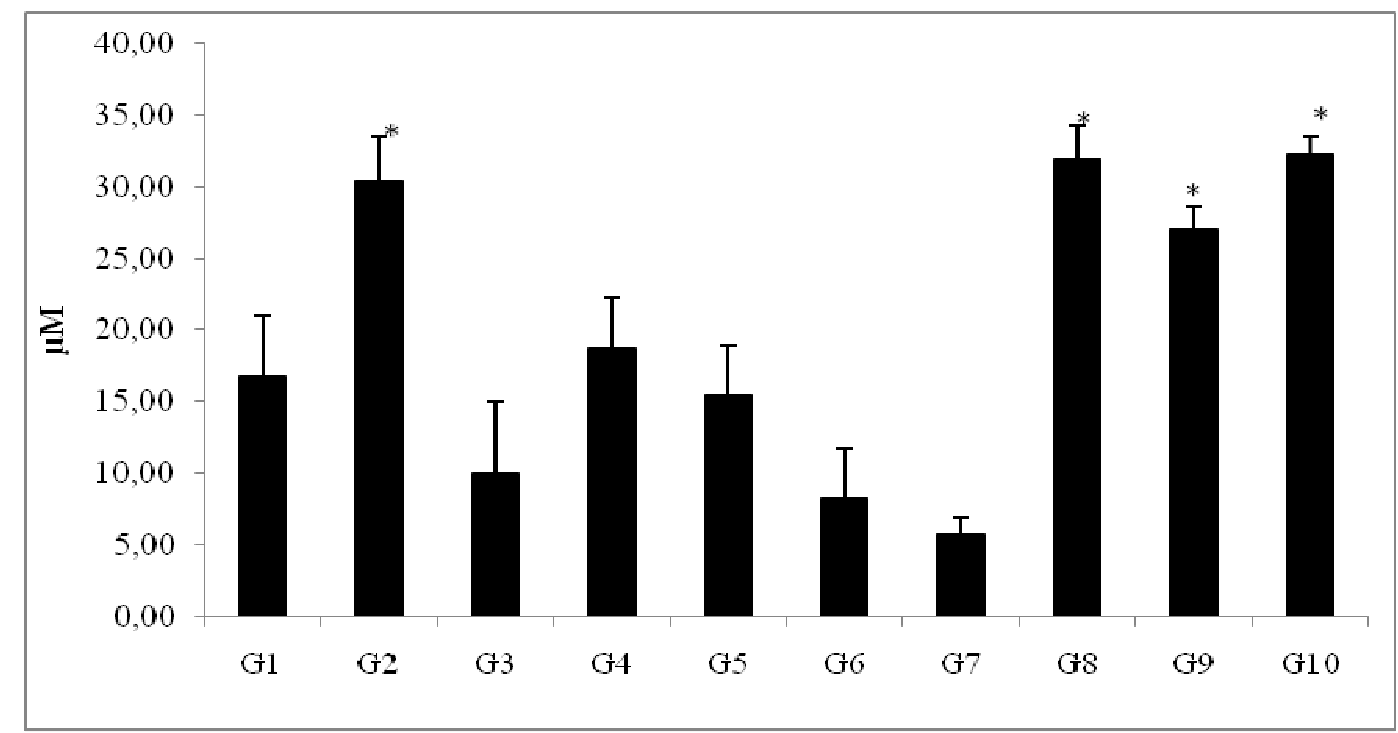

The vertical bars represent the amount of NO production in each group (in $\mu \mathrm{M})$.

* Groups with significant statistic differences $(\mathrm{P}<0.05)$.

Source: Elaboration of the authors.

\section{Lung flow cytometry}

There was no significant amount of $\mathrm{CD}^{+}$and $\mathrm{CD}^{+} \mathrm{T}$ lymphocytes, only mononuclear cells (macrophages and monocytes) were present in large amounts. This result suggests that the main population of leukocytes recruited in the lung tissue to fight against BI might be the macrophage
(Figure 3). Although it was not possible to observe a significant difference between groups $(\mathrm{P}>0.05)$, the histograms show an increase in the macrophage population in vaccinated and challenged birds treated with high doses of vitamin E (Figure $3 \mathrm{~B}, \mathrm{C}$, $\mathrm{D}$, and E), compared to control . 
Figure 3. Flow cytometry histogram of mononuclear cells (macrophages and monocytes) in the lungs of birds positive control group and groups with different doses of vitamin E and vaccinated and challenged. (A) Group 1 - positive control only challenged; (B) Group 4 - birds without vitamin E supplementation, vaccinated and challenged; (C) Group 6 - birds with $15 \mathrm{IU} / \mathrm{kg}$ of vitamin E, vaccinated and challenged; (D) Group 8 - birds with 50 IU/kg of vitamin E, vaccinated and challenged; (E) Group 10 - birds with $200 \mathrm{IU} / \mathrm{Kg}$ of vitamin E, vaccinated and challenged.
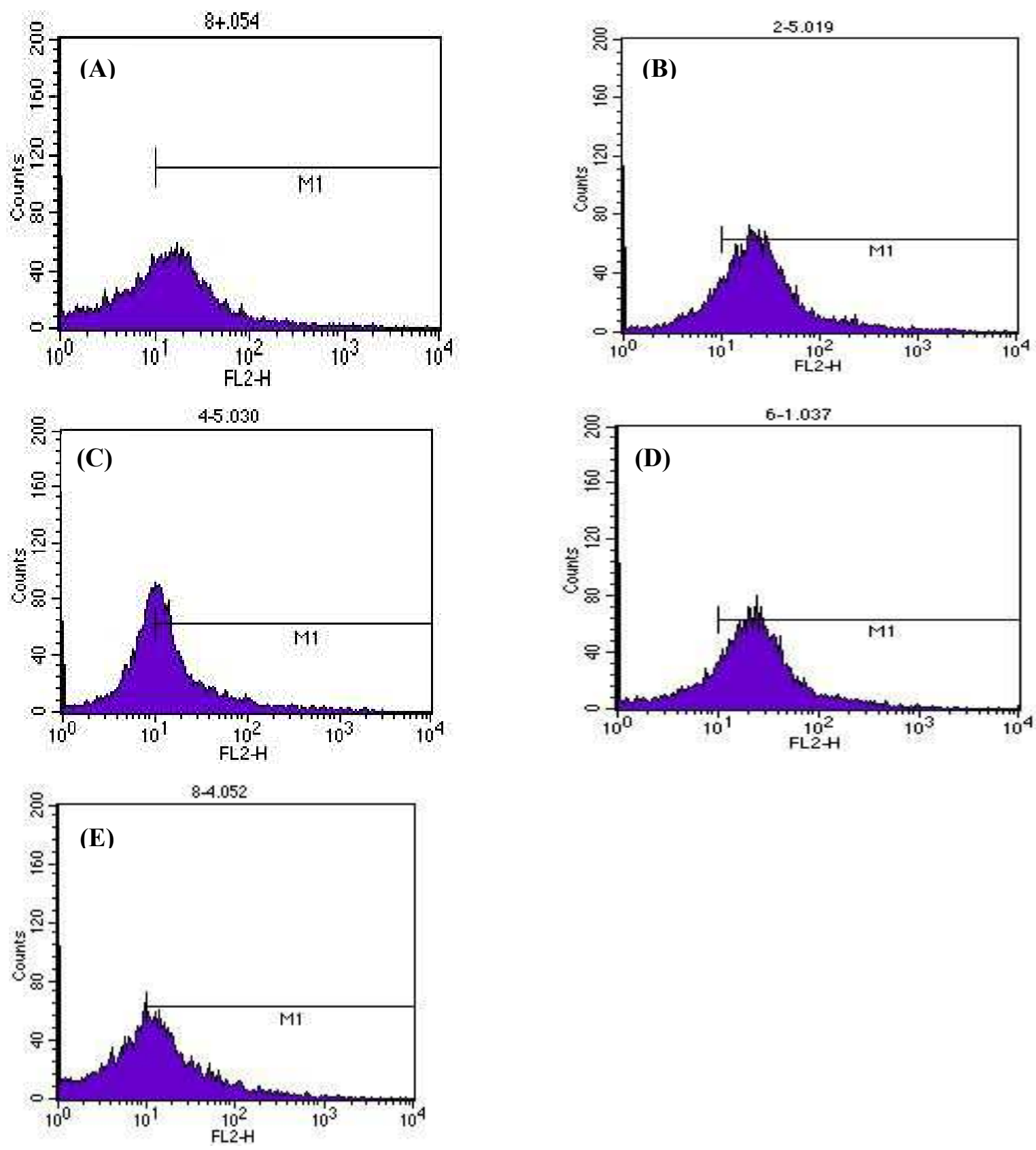

Source: Elaboration of the authors. 


\section{Clinical signs and mortality}

During the experiment it was not observed clinical signs and/or bird mortality. On the fifth day after challenge only the birds of the positive control group showed mild hoarseness.

\section{Virus isolation test}

To evaluate the vaccine efficiency, the technique used was the virus isolation in embryonated eggs. All groups vaccinated and challenged (4, 6, 8, and $10)$, except the group six had good protection (80 to $100 \%$ ).

The group six had no satisfactory protection $(40 \%)$. This result could be due to vaccination response which may, in some cases, cause changes in the embryo but not influenced by the dose of supplementation. Only vaccinated groups (3, 5, 7, and 9) showed normal embryos, an expected result. The control groups (1 and 2) showed satisfactory results, the negative control without any modification embryonic while the positive control showed in all embryos, characteristic changes as dwarfism, bad warping and winding. We can therefore conclude that vaccination was effective.

\section{Histopathology}

Lung, trachea, kidney, spleen, and thymus were examined, however lesions of IBV were found only in the trachea. The tracheas of the negative control group showed no lesions, showing normal ciliary epithelium. In group 1 (birds that received only challenge) were found all the changes described as positive for IBV infection: ciliary loss, edema, and hyperplasia in the lamina propria with mononuclear infiltration and congestion. Others groups showed no changes.

\section{Discussion}

This study was conducted in order to analyze the best immunomodulator dosage of vitamin $\mathrm{E}$, and what is its real effect on the innate and cellular immune system of birds vaccinated and challenged with IBV. Macrophages play a major role in the adaptive and innate immune response. They participate in phagocytic and microbicidal system through the production of cytokines and nitric oxide, being a potent effector cell in combating the infectious agents (HE; GENOVESE; KOGUT, 2011; QURESHI, 2003). It is also known that avian macrophages are able to produce NO under various immunological stimuli and its function is essential to the immune system (HUSSAIN; QURESHI, 1997).

The results obtained in this experiment demonstrate a positive effect on microbicidal activity of abdominal macrophages and also NO production in birds supplemented with higher doses of vitamin E (200 IU/kg). Therefore that vitamin E is able to potentiate the action of macrophages and NO production in the innate immune response.

Corroborating with the findings of this study, Niu et al. (2009) showed an increase in the number and activity in abdominal macrophages from birds under heat stress with higher dosages of vitamin $\mathrm{E}$ supplementation (100 and $200 \mathrm{mg} / \mathrm{kg}$ ). Konjufca et al. (2004) also observed an improvement in the phagocytic activity of macrophages in young birds with high doses of vitamin E supplementation (110$220 \mathrm{mg} / \mathrm{kg}$ ). However, the study made by Gore and Qureshi (1997) showed a better response of phagocytic macrophages and NO increased in the dose of $10 \mathrm{IU} / \mathrm{kg}$ via the egg, thus improving the quality of chicks and turkeys post-hatching. These authors suggest that the increase of NO in birds supplemented with vitamin $\mathrm{E}$ is not fully understood. The data suggest that there is an increase in the affinity of the membrane receptors for activation of macrophages, which can cause also an increase of iNOS activity.

The studies related to vitamin $\mathrm{E}$ with phagocytosis, for the most part, not used the Salmonella Enteritidis to test macrophages. Although 
it is known that Salmonella spp may survive inside macrophages, these cells also possess mechanisms capable to kill the bacterium. Study carried out by Tengerdy and Brown (1977) reports an increase in the mononuclear phagocyte system observed in birds supplemented with $300 \mathrm{mg} / \mathrm{kg}$ of vitamin $\mathrm{E}$ compared to the basal group, showing an increase in protection against microbial pathogens such as Escherichia colli. However, it is important to know that in the study done by He, Genovese and Kogut (2011), which analyzed macrophage cultures front of stimulation of cytokines, these cells when placed in contact with Salmonella Enteritidis showed no differences in their phagocytic and microbicide ability. In the same way, the production of nitric oxide was not affected. This study also aimed to evaluate whether supplementation of vitamin $\mathrm{E}$ enhances the vaccination, against IB. Although IB control is made by schematic vaccination of the birds, the dissemination of this disease is far from over. There are several studies about IB, mainly about the real role of the immune response induced by the disease or their vaccination, which is not yet fully understood.

It is known that the IBV or its vaccination stimulates both the humoral and cellular immune response. Leshchinsky and Klasing (2001) analyzed the humoral immune response using attenuated and inactivated IBV vaccines and supplemented with several concentrations of vitamin $\mathrm{E}(10,17.5,25$, $37.5,50,100$, and $200 \mathrm{UI} / \mathrm{kg})$. They found that moderate levels of this vitamin $(25 \mathrm{IU} / \mathrm{kg}$ ) had greater immunomodulatory effect when compared with higher levels. Other studies also confirm an enhancement of vaccination with vitamin $\mathrm{E}$ supplementation (FRANCHINI et al., 1991, 1995).

Research suggests that although the antibodies play an important role in IB other immunological factors must be involved, such as cell response (COOK, 1991). Collisson et al. (2000) observed an increased in the cellular immune response mediated by $\mathrm{T}$ cells (CTL) in birds with IB associated with resolution of clinical signs and the virus itself.
This study promoted the transfer of CD8 from birds infected with IBV to uninfected birds, thus transferring protection against IBV.

In relation to the viral isolation vaccinated, challenged and supplemented with vitamin E (group 6) birds were positive, obtaining a lower protection rate for this group. However, these birds did not show clinical signs of disease, thus collaborating with other authors (TORO, 2010; NASCIMENTO; COMERLATOL; SPILKIL, 2013), which indicates that the vaccine may cause embryo changes in embryo leading to viral recovery.

Analyzing the cellular immunity, our results suggest that the main population of leukocytes recruited in lung tissue to fight against IBV is the macrophage because mononuclear cells were found in much higher numbers. Since this type of phagocyte composes the effector cells in the immune response to the virus, we can conclude that migration is a normal response to the disease, but this action was enhanced by the addition of vitamin $\mathrm{E}$, regardless of dosage.

In the literature there are reports that cellular immunity is the main resource of the poultry immune system to fight IBV, thus indicating that NO functionmay be directly involved in the response against the virus (COLLISSON et al., 2000; PEI; BRILES; COLISSON, 2003; PEI et al., 2001). However, the amount of NO produced by the macrophages within the various treatments performed with IBV, shows that there is no difference in the capacity of nitrogen reagents with supplementation of vitamin E. This fact can be explained due some variability, because the expression of iNOS can be detected in various cell types, and its expression can be affected by many factors such as pulmonary hypertension, hypoxia, and inflammatory stimuli and it may also vary depending on the strain used (BOWEN et al., 2006; CHAPMAN; WIDEMAN, 2006).

These findings from the literature emphasize the importance of vitamin E, proving at stimulating 
function on bird immune system. In addition, it can be suggested that vitamin E supplementation enhances the microbicidal action of macrophages and NO production against Salmonella spp, thus playing an important role in the innate immune response of birds. It can be concluded also, that the macrophages are the most cells recruited to the lung in the IBV against infection and that this population may be increased by vitamin E supplementation, independently of the dosage used.

\section{Conclusion}

The results of this study demonstrate that supplementation of vitamin $E$ in poultry is important because it stimulates the immune response of the birds.

Vitamin E when in high dosage (200 IU/ $\mathrm{kg}$ ) is capable of enhancing the microbicidal abdominal macrophage action against the culture of Salmonella Enteritidis, as well as induces NO production, helping the innate immune response in SPF chickens. And, it also influences the number of macrophages in the lungs of vaccinated birds challenged with IBV, highlighting the importance of this cell in the response against IB.

\section{Acknowledgments}

State University of Santa Catarina (UDESC), Embrapa - Suínos e Aves, The University of São Paulo (USP), State University of Londrina (UEL), and Coordination of perfecting to Higher Education Personnel (CAPES).

\section{References}

BOWEN, O. T.; WIDEMAN, R. F.; ANTHONY, N. B.; ERF, G. F. Variation in the pulmonary hypertensive responsiveness of broilers to lipopolysaccharide and innate variation in nitric oxide production by mononuclear cells. Poultry Science, Champaign, v. 85, n. 8, p. 13491363, 2006.
CAMPBELL, S. G.; DESIDERIO, J. V. Intraphagocytic killing of Salmonella typhimurium by liposomeencapsulated cephalothin. The Journal of Infectious Diseases, Oxford, v. 148, n. 3, p. 563-570, 1983.

CHAPMAN, M. E.; WIDEMAN JUNIOR, R. F. Evaluation of total plasma nitric oxide concentrations in broilers infused intravenously with sodium nitrite, lipopolysaccharide, aminoguanidine, and sodium nitroprusside. Poultry Science, Champaign, v. 85, n. 2, p. 312-320, 2006.

COLLISSON, E. W.; PEI, J.; DZIELAWA, J.; SEO, S. $\mathrm{H}$. Cytotoxic T lymphocytes are critical in the control of infectious bronchitis virus in poultry. Developmental; Comparative Immunology, Edinburgh, v. 24, n. 2-3, p. 187-200, 2000.

COOK, M. E. Nutrition and the immune response to the domestic fowl. Critical Reviews in Poultry Biology, Boca Raton, v. 3, n. 3, p. 167-189, 1991.

FRANCHINI, A.; BERTUZZI, S.; TOSARELLI, C.; MANFREDA, G. Vitamin E in viral inactivated vaccines. Poultry Science, Champaign, v. 74, n. 4, p. 666-671, 1995.

FRANCHINI, A.; CANTI, M.; MANFREDA, G.; BERTUZZI, S. Vitamin E as adjuvant in emulsified vaccine for chicks. Poultry Science, Champaign, v. 70, n. 8, p. 1709-1715, 1991.

GORE, A. B.; QURESHI, M. A Enhancement of humoral and cellular immunity by vitamin $\mathrm{E}$ after embryonic exposure. Poultry Science, Champaign, v. 76, n. 7, p. 984-991, 1997.

GREEN, L. C.; TANNENBAUM, S. R.; GOLDMAN, P. Nitrate synthesis in the germfree and conventional rat. Science, Washington, v. 212, n. 4490, p. 56-8, 1981.

HE, H.; GENOVESE, K. J.; KOGUT, M. H. Modulation of chicken macrophage effector function by Th1/Th2 cytokines. Cytokine, Sheffield, v. 53, n. 3, p. 363-369, 2011.

HUSSAIN, I.; QURESHI, M. A. Nitric oxide synthase and mRNA expression in chicken macrophages, Poultry Science, Champaign, v. 76, n. 11, p. 1524-1530, 1997.

KIDD, M. T. Nutritional modulation of immune function in broilers. Poultry Science, Champaign, v. 83, n. 4, p. 650-657, 2004.

KLASING, K. C. Nutritional modulation of resistance to infectious diseases. Poultry Science, Champaign, v. 77, n. 8, p. 1119-1125, 1998.

KONJUFCA, V. K.; BOTTJE, W. G.; BERSI, T. K.; ERF, G. F. Influence of dietary vitamin E on phagocytic functions of macrophages in broilers. Poultry Science, Champaign, v. 83, n. 9, p. 1530-1534, 2004. 
LESHCHINSKY, T. V.; KLASING, K. C. Relationship between the level of dietary vitamin $\mathrm{E}$ and immune response of broiler chickens. Poultry Science, Champaign, v. 80, n. 11, p. 1590-1599, 2001.

MAST, J.; GODDEERIS, B. M.; PEETRS, K.; VANDESANDE, F.; BERGHMAN, L. R. Characterization of chicken monocytes, macrophages and interdigitating cells by the monoclonal antibody KUL01. Veterinary Immunology and Immunopathology, Amsterdam, v. 61, n. 2-4, p. 343-357, 1998.

NASCIMENTO, B.; COMERLATO, J.; SPILKI, F. R. Detecção molecular de vírus da bronquite infecciosa em plantéis de avós, matrizes e frangos de corte no Rio Grande do Sul e Mato Grosso. Ciência Rural, Santa Maria, v. 43, n. 3, p. 474-479, mar. 2013.

NIU, Z. Y.; LIU, F. Z.; YAN, Q. L.; LI, W. C. Effects of different levels of vitamin $\mathrm{E}$ on growth performance and immune responses of broilers under heat stress. Poultry Science, Champaign, v. 88, n. 10, p. 2101-2107, 2009.

PEI, J.; BRILES, W. E.; COLLISSON, E. W. Memory T cells protect chicks from acute infectious bronchitis vírus infection. Virology, Seattle, v. 306, n. 2, p. 376-384, 2003.

PEI, J.; SEKELLICK, M. J.; MARCUS, P. I.; CHOI, I.; COLLISON, E. W. Chicken interferon type I inhibits infectious bronchitis virus replication and associated respiratory illness. Journal of Interferon and Cytokine Research, Cleveland, v. 21, n. 12, p. 1071-1077, 2001.

QURESHI, M. A. Avian macrophage and immune response: an overview. Poultry Science, Champaign, v. 82, n. 5, p. 691-698, 2003.
ROSTAGNO, H. S.; ALBINO, L. F. T.; DONZELE, J. L.; GOMES, P. C.; OLIVEIRA, R. F.; LOPES, D. C.; FERREIRA, A. S.; BARRETO, S. L. T.; EUCLIDES, R. F. Tabelas brasileiras para aves e suínos: composição de alimentos e exigências nutricionais. 3. ed. Viçosa: UFV/ DZO, 2011. 252 p.

SABET, T.; HSIA, W.; STANISZ, M.; DOMEIRI, A.; ALTEN, P. V. A simple method for obtaining peritoneal macrophages from chickens. Journal of Immunological Methods, Aliso Viejo, v. 14, n. 2, p. 103-110, 1977.

TENGERDY, R. P.; BROWN, J. C. Effect of vitamin $\mathrm{E}$ and $\mathrm{A}$ on humoral immunity and phagocytosis of Escherichia coli infected chickens. Poultry Science, Champaign, v. 56, n. 3, p. 957-963, 1977.

TORO, H. Infectious bronchitis virus: dominance of ArkDPI-type strains in the United States broiler industry during the last decade. Revista Brasileira de Ciência Avícola, Campinas, v. 12, n. 2, p. 79-86, 2010.

TREMBICKI, K. A.; QURESHI, M. A.; DIETERT, R. R. Avian peritoneal exudate cells: a comparison of stimulation protocols. Developmental; Comparative Immunology, Edinburgh, v. 8, n. 2, p. 395-402, 1984.

WORLD ORGANISATION FOR ANIMAL HEALTH - OIE. Chapter 2.3.2. Avian infectious bronchitis. In: Manual of diagnostic tests and vaccines for terrestrial animals. Paris: OIE, 2008. Available at: $<$ http://www.oie. int>. Accessed at: 10 set. 2010. 
